Vol 1. No. 4, Oktober 2021 P-ISSN : 2774-8014, e-ISSN : 2774-7034

\title{
PENGGUNAAN MEDIA BUKU CERITA BERGAMBAR UNTUK MENINGKATKAN KETERAMPILAN MENDESKRIPSIKAN BAGI SISWA KELAS VI SDN 015/VIII SUNGAI BENGKAL
}

\author{
SUSMARNI \\ SD Negeri 015/VIII Sungai Bengkal Kabupaten Tebo Provinsi Jambi \\ susmarni158@yahoo.com
}

\begin{abstract}
ABSTRAK
Penelitian ini bertujuan untuk mengetahui penggunaan media buku cerita bergambar untuk meningkatkan keterampilan mendeskripsikan siswa kelas VI SD Negeri 015/VIII Sungai Bengkal Kabupaten Tebo Provinsi Jambi Tahun Pelajaran 2019/2020. Jenis penelitian ini adalah Penelitian Tindakan Kelas kolaborasi yang dilakukan sebanyak dua siklus. Desain penelitian menggunakan model Kemmis dan Taggart dengan subjek penelitian siswa kelas VI yang berjumlah 20 siswa. Teknik pengumpulan data menggunakan 1) tes mendeskripsikan lisan dan tes tertulis, 2) observasi, dan 3) dokumentasi. Teknik analisis data menggunakan analisis statistik deskriptif. Indikator keberhasilan siswa yang harus dicapai dengan rata-rata kelas 75 . Hasil penelitian menunjukkan bahwa pembelajaran mendeskripsikan dengan menggunakan media buku cerita bergambar dapat meningkatkan keterampilan mendeskripsikan siswa kelas VI SD Negeri 015/VIII Sungai Bengkal Kabupaten Tebo. Berdasarkan hasil kemampuan mendeskripsikan siswa dengan menggunakan media buku cerita bergambar pada siklus 1 pertemuan 1 diperoleh data $62,35 \%$, pada siklus 1 pertemuan 2 diperoleh hasil 63,3\%. Target pencapaian dari penelitian ini adalah 75\%. Maka berdasarkan data pada siklus 1 baik pertemuan 1 dan 2 belum mencapai $75 \%$. Oleh sebab itu, penelitian ini berlanjut pada siklus 2 . Selanjutnya pada siklus 2 pertemuan 1 diperoleh $83,3 \%$ dan pada siklus 2 pertemuan 2 mencapai 85,5\%. Berdasarkan analisis pada siklus 2 maka nilai yang diharapkan telah tercapai. Peneliti dapat menyimpulkan bahwa penggunaan buku cerita bergambar dapat meningkatkan keterampilan mendeskripsikan siswa kelas VI SD Negeri 015/VIII Sungai Bengkal Kabupaten Tebo.
\end{abstract}

Kata Kunci: media buku cerita bergambar, keterampilan mendeskripsikan siswa

\section{PENDAHULUAN}

Pendidikan merupakan bagian penting dari kehidupan manusia maupun pencapaian pembangunan suatu bangsa. Pendidikan begitu penting bagi kehidupan manusia karena manusia dapat menentukan dan mengubah kehidupan yang dijalani melalui pendidikan. Pendidikan bermakna merupakan pendidikan yang efektif dimana siswa belajar secara aktif dan terlibat secar aktif-partisipatif dalam mengkonstruksi pengetahuannya dengan bimbingan dan fasilitas guru (Mustadi, 2020). Pendidikan adalah proses perubahan tingkah laku, penambahan ilmu pengetahuan dan pengalaman hidup agar peserta didik menjadi lebih dewasa dalam pemikiran dan sikap. Pendidikan di era digital saat ini sangatlah pesat, kemajuan dalam bidang teknologi tidak hanya dinikmati oleh orang dewasa saja, siswa-siswa usia sekolah dasar juga sudah bisa menikmati dari hasil perkembangan teknologi saat ini. Teknologi banyak dimanfaatkan dalam dunia pendidikan, sebagai sarana dan prasarana interaksi antara pendidik dan peserta didik (Putri, 2018). Pendidikan sebagai upaya menyiapkan peserta didik bagi perannya di masa mendatang, mempunyai peran yang sangat strategis dalam meningkatkan kualitas sumber daya manusia dan upaya mewujudkan cita-cita bangsa Indonesia (Maisaro, dkk, 2018).

Mendeskripsikan merupakan suatu aktivitas yang dilakukan untuk mendapatkan sebuah informasi, memperoleh ilmu pengetahuan serta pengalaman-pengalaman baru. Mendeskripsikan juga merupakan satu keterampilan penting yang diperlukan untuk sukses dalam semua pelajaran, oleh karena itu sebuah keharusan mendeskripsikan diciptakan (Candra, dkk, 2018). Kegiatan mendeskripsikan juga merupakan usaha memahami informasi yang disampaikan melalui lambang tulisan. Namun kegiatan mendeskripsikan merupakan aktivitas 


\section{ELEMENTARY : Jurnal Inovasi Pendidikan Dasar Vol 1. No. 4, Oktober 2021 P-ISSN : 2774-8014, e-ISSN : 2774-7034}

yang unik dan rumit, sehingga seorang tidak dapat melakukan hal tersebut tanpa mempelajarinya, terutama pada siswa usia sekolah dasar (Rahayu, dkk, 2016). Masalah yang sering dihadapi siswa usia sekolah dasar dalam mendeskripsikan adalah pada pelaksanaan pengajaran mendeskripsikan, guru seringkali dihadapkan pada siswa yang mengalami kesulitan mendeskripsikan, baik yang berkenaan dengan hubungan huruf, suku kata, kata, kalimat sederhana, maupun ketidakmampuan siswa memahami isi bacaan. Menurut Smith et., al, (2012) manusia memerlukan waktu lebih lama untuk mendeskripsikan huruf-huruf yang tidak berkaitan daripada mendeskripsikan huru-huruf yang membentuk sebuah kata. Berdasarkan Kurikulum Tingkat Satuan Pendidikan (KTSP), standar kompetensi yang digunakan yaitu memahami ragam dan wacana tulis dengan mendeskripsikan nyaring dan mendeskripsikan dalam hati dengan kompetensi dasar bahasa Indonesia kelas VI khususnya mendeskripsikan, yaitu 1) siswa mampu mendeskripsikan nyaring teks (15-20 kalimat) dengan memperhatikan lafal dan intonasi yang tepat, dan 2) menyebutkan isi teks agak panjang (20-25 kalimat) yang dibaca dalam hati. Mendeskripsikan merupakan keterampilan yang sangat penting, sehingga keterampilan mendeskripsikan diajarkan pada jenjang pendidikan mulai dari Sekolah Dasar (SD) hingga perguruan Tinggi. Pembelajaran mendeskripsikan permulaan ditunjukkan untuk siswa di kelas awal, yaitu I, II, dan III, untuk kelas atas yaitu kelas IV, V dan VI merupakan pembelajaran mendeskripsikan pemahaman atau lanjutan (Andriani, 2015: 153). Pembelajaran mendeskripsikan permulaan di sekolah dasar bertujuan agar siswa mengenal dan menguasai sistem tulisan sehingga mereka dapat mendeskripsikan dengan menggunakan sistem tersebut. Siswa sekolah dasar harus mampu mendeskripsikan dengan tepat. Ketepatan mendeskripsikan permulaan siswa sangat dipengaruhi oleh keaktifan dan kreativitas guru yang mengajar di kelas rendah. Keberhasilan belajar siswa dalam mengikuti proses kegiatan pembelajaran ditentukan oleh penguasaan kemampuan mendeskripsikan mereka. Banyak pakar pendidikan mencari solusi bagaimana cara memperbaiki pembelajaraan kemampuan mendeskripsikan permulaan. Belajar mendeskripsikan permulaan sebaiknyaa dilakukan melalui gambar-gambar dengan kata-kata sederhana (Farihatin, 2013). Menurut Tarigan dalam (Tanggulungan, 2014: 227-228) langkah awal yang paling penting dalam pembelajaran mendeskripsikan permulaan adalah bagaimana menarik minat dan perhatian siswa agar mereka merasa tertrik dengan buku bacaan dan mau belajar dengan keinginannya sendiri tanpa merasa terpaksa untuk melakukannya. Bercerita dengan media buku menjadi stimulasi yang efektif bagi siswa, serta dengan mendeskripsikan cerita, guru dapat memberikan contoh yang efektif bagi siswa bagaimana aktivitas mendeskripsikan yang harus dilakukan. Secara tidak langsung, siswa memperoleh contoh tentang orang yang gemar dan pintar mendeskripsikan dari apa yang dilihatnya. Apabila sering memperoleh contoh, minat baca siswa akan tumbuh secara suka rela. Siswa pun akan belajar mengidentifikasi lambang-lambang tulisan dalam rangkaian kata dan dalam rangkaian kalimat (Nurkhaula, 2018). Media gambar sangar cocok untuk diterapkan pada kelas VI sekolah dasar dalam upaya meningkatkan kemampuan mendeskripsikan permulaan, menurut teori Piaget dalam (Juwantara, 2019) siswa usia sekolah dasar ada pada tahap operasional konkret. Buku cerita bergambar dengan warna-warni yang mencolok dan gambar yang menarik akan merangsang siswa untuk mendeskripsikan sekaligus menggugah rasa ingin tahunya.

Berdasarkan hasil observasi di lapangan, pembelajaran mendeskripsikan di SD Negeri 015/VIII Sungai Bengkal Kabupaten Tebo mengungkapkan bahwa terdapat beberapa siswa yang masih kurang lancar dalam mendeskripsikan, artinya siswa memiliki keterampilan mendeskripsikan yang masih rendah. Hal tersebut dikarenakan oleh beberapa faktor, yaitu siswa kurang aktif dalam mengikuti kegiatan pembelajaran, hal tersebut disebabkan karena siswa kurang siap menerima pembelajaran, serta kurangnya interaksi yang baik dengan guru, selain itu pembelajaran yang dilaksanakan oleh guru kurang sesuai serta tidak menggunakan media atau alat peraga sehingga siswa cenderung terasa bosan dan kurang termotivasi dalam mengikuti pembelajaran. Buku cerita bergambar yang ada di kelas tidak dipergunakan sebagaimana mestinya, padahal buku cerita bergambar tersebut dapat digunakan untuk menarik perhatian siswa dalam mengikuti pembelajaran khususnya mendeskripsikan. Berdasarkan 
uraian di atas maka peneliti memberikan suatu inovasi berupa pemanfaatan media yang telah tersedia untuk kegiatan pada saat proses pembelajaran berkolaborasi dengan guru kelas VI SD Negeri 015/VIII Sungai Bengkal Kabupaten Tebo. Diharapkan dengan menggunakan media buku cerita bergambar diharapkan dapat menarik perhatian siswa terhadap pelajaran mendeskripsikan, sehingga siswa tidak lagi mengalami kesulitan dalam mendeskripsikan, sehingga mampu meningkatkan keterampilan mendeskripsikan.

\section{METODE PENELITIAN}

Penelitian ini merupakan Penelitian Tindakan Kelas (PTK), karena penelitian ini dilakukan untuk memecahkan masalah pembelajaran di dalam kelas yang di dalamnya berusaha mengkaji beberapa aspek kegiatan belajar-mengajar, seperti keterlaksanaan rencana pembelajaran dan kemampuan bahasa siswa. Dalam Penelitian ini menggunakan pendekatan deskriptif kualitatif dan kuantitatif dengan subjek penelitian hanya satu kelas, dengan pembelajaran menggunakan Media Buku Cerita Bergambar. Peneliti ingin mendeskripsikan penerapan pembelajaran menggunakan Media Buku Cerita Bergambar yang dapat meningkatkan Kemampuan Mendeskripsikan siswa.

Dalam melakassiswaan Penelitian Tindakan Kelas, sejumlah kegiatan dilaksanakan secara berulang-ulang mulai dari tahapan perencanaan, pelaksanaan, dan refleksi merupakan serangkaian kegiatan yang utuh yang membentuk suatu siklus. Setiap siklus terdiri atas 4 tahapan (Arikunto, 2010:16), yaitu: (a) Perencanaan (Planning), (b) Pelaksanaan (Acting), (c) Pengamatan (Observing), (d) Refleksi (Reflecting). Dalam tahap perencanaan ini peneliti melakukan 5 kegiatan utama, yaitu: Meneliti kelas, menentukan tindakan, membuat RPPH dan Alat peraga, Menyusun Instrumen Penelitian, Membuat lembar observasi. Subjek dalam penelitian ini adalah siswa kelas VI SD Negeri 015/VIII Sungai Bengkal Kabupaten Tebo Provinsi Jambi Tahun Pelajaran 2019/2020 sebanyak 20 siswa, terdiri dari 12 laki-laki dan 8 perempuan.

\section{HASIL DAN PEMBAHASAN}

Dalam hal ini akan dijelaskan tentang kegiatan yang dilakukan peneliti untuk menjawab permasalahan yang telah disebutkan di atas. Proses penelitian guru mendapatkan hasil penelitian ini mencakup beberapa tahapan sebagai berikut:

\section{Tahap Persiapan}

Sebelum peneliti melakukan penelitian ke lapangan untuk mengumpulkan data, peneliti mempersiapkan hal-hal sebagai berikut: 1) Penentuan Masalah dan Judul Penelitian, 2) Pelaksanaan Studi Pendahuluan, 3) Penyusunan proposal Penelitian dan Ijin Penelitian.

\section{Tahap Pelaksanaan}

Penelitian Tindakan Kelas (PTK) tentang meningkatkan keterampilan mendeskripsikan siswa kelas VI SD Negeri 015/VIII Sungai Bengkal Kabupaten Tebo Provinsi Jambi Tahun Pelajaran 2019/2020 melalui media buku cerita bergambar dengan subyek penelitian sebanyak 20 siswa yang telah dilaksanakan melalui 2 siklus dengan hasil penelitian sebagai berikut:

\section{Siklus I}

\section{Penyusunan Rencana Tindakan}

Dalam siklus I pertemuan I dilaksanakan penyusunan Rencana Pelaksanaan Pembelajaran (RPPH) yang akan digunakan dalam pembelajaran disesuaikan dengan tema yang ada. Siklus I pertemuan I ini dilaksanakan pada tanggal 5 Oktober 2019. Indikator yang ingin dicapai yaitu kemampuan mengenal dan mengerti semua huruf dan bentuk-bentuknya, dapat menghubungkan antara kalimat dan gambar, mengenal kosakata baru berikut gambarannya, dapat membedakan dan membuat kata dari suku kata awal dan suku kata akhir, dapat mendeskripsikan kata-kata yang terdiri dari dua, tiga atau empat buku cerita bergambar. Selain itu peneliti mempersiapkan alat observasi yang akan digunakan dalam mengamati kegiatan pembelajaran dari kegiatan awal sampai akhir yang dilakukan guru dalam melakssiswaan pembelajaran. 


\section{Pelaksanaan Tindakan}

Pada tahap ini, kegiatan yang dilakukan adalah melakssiswaan tindakan sesuai dengan rencana pembelajaran yang telah disusun. Adapun urutan kegiatan secara garis besar adalah sebagai berikut: 1) Kegiatan Awal, 2) Kegiatan Inti, 3) Kegiatan Akhir

\section{Observasi}

Hasil pengamatan yang dilakukan peneliti dalam mengamati kegiatan siswa dan guru yang digunakan dalam proses pembelajaran dengan instrument yang ada. Adapun pengolah data hasil observasi aktivitas siswa, aktivitas guru dan hasil belajar siswa adalah sebagai berikut: (1) Observasi Aktivitas Siswa, Aktivitas siswa dalam kegiatan bercerita menunjukkan persentase pertemuan I, 54\%, ini berarti siswa belum termotivasi dan belum mencapai target seperti yang diharapkan. (2) Observasi Aktivitas Guru, Pengamatan terhadap guru dilakukan oleh teman sejawat pada saat proses kegiatan bercerita dan menghasilkan pertemuan I, 58,3\%.

\section{Refleksi}

Berdasarkan pengamatan peneliti pada pembelajaran kegiatan bercerita untuk meningkatkan keterampilan mendeskripsikan siswa kelas VI SD Negeri 015/VIII Sungai Bengkal Kabupaten Tebo Provinsi Jambi Tahun Pelajaran 2019/2020 pada siklus I pertemuan I merefleksikan sebagai berikut:

Pada saat awal siklus I, pelaksanaan belum sesuai dengan rencana. Hal ini disebabkan karena: 1) Sebagian siswa belum banyak beraktivitas sesuai dengan yang diharapkan, 2) Sebagian siswa belum dapat berkonsentrasi dan perhatian secara utuh dan menyeluruh, 3) Siswa masih belum tertarik untuk mengikuti kegiatan bercerita beberapa siswa yang memerlukan motivasi dalam kegiatan, 4) Dari pengamatan teman sejawat, guru dalam menyampaikan materi bercerita masih belum dapat memotivasi siswa untuk mendengarkan cerita. Cerita yang disampaikan oleh guru terlalu cepat. Intonasi, mimik dan suara yang disampaikan guru monoton sehingga kurang melibatkan konsentrasi dan perhatian siswa, hanya siswa tertentu saja yang dapat mengikuti dengan baik.

Dari hasil diskusi dan refleksi maka peneliti bersama kolabolator merencsiswaan pembelajaran pertemuan selanjutnya dengan memperbaiki kelemahan yang ada pada pertemuan I yaitu mengajak siswa agar terlibat secara aktif dalam pembelajaran. Peranan guru dalam menyampaikan cerita tidak terlalu cepat dan hendaknya cerita disampaikan dengan ekspresi dan intonasi sesuai dengan alur cerita. Rendahnya persentase ketuntasan dari ketetapan yang dikehendaki atau belum memenuhi target yang ditetapkan yaitu minimal $75 \%$ siswa menguasai materi maka dilanjutkan pertemuan II.

\section{Siklus II}

Dalam siklus II pertemuan I dan II dilaksanakan penyusunan Rencana Pelaksanaan Pembelajran Harian (RPPH) yang akan digunakan dalam pembelajaran disesuaikan dengan tema yang ada. Siklus II pertemuan I ini dilaksanakan pada tanggal, 12 Oktober 2019. Indikator yang ingin dicapai yaitu kemampuan memahami secara lanjut buku cerita bergambar yang telah dibaca lalu kemudian siswa mampu mendeskripsikan hasil bacaannya, dapat menghubungkan dan merangkum antara bacaan dan gambar, mengenal letak informasi tiap bacaan berikut gambarannya, dapat membedakan dan membuat rangkuman informasi dari tiap bacaan, dapat mendeskripsikan paragraf yang terdiri dari dua, tiga atau empat buku cerita bergambar. Selain itu peneliti mempersiapkan alat observasi yang akan digunakan dalam mengamati kegiatan pembelajaran dari kegiatan awal sampai akhir yang dilakukan guru dalam melakssiswaan pembelajaran. Pelaksanaan Tindakan Pelaksanaan kegiatan pembelajaran untuk siklus II dilaksanakan pada tanggal 12 Oktober 2019 di kelas VI dengan jumlah siswa 20 siswa. Dalam penelitian ini, peneliti bertindak sebagai observer. Adapun proses pembelajaran pada skenario pembelajaran yang termuat dalam rencana pelaksanaan pembelajaran yang telah disiapkan sebelumnya. Pelaksanaan tindakan ini adalah proses pembelajaran yang dilakukan guru dari awal hingga akhir dengan langkah-langkah pembelajaran sebagai berikut: 1) Kegiatan Awal, 2) Kegiatan Inti, 3) Kegiatan Akhir. 


\section{Observasi}

Observasi Aktivitas Siswa dalam kegiatan mendeskripsikan buku cerita bergambar menunjukkan pada pertemuan II meningkat menjadi 83,3\% ini berarti siswa sudah termotivasi dan sudah mencapai target seperti yang diharapkan Observasi Aktivitas Guru Pengamatan terhadap guru dilakukan oleh teman sejawat pada saat proses kegiatan bercerita pertemuan II meningkat memperoleh persentase $87,5 \%$

Dari hasil pengolahan dan analisis data baik dari pengamatan yang dilakukan siklus I dan siklus II secara keseluruhan telah disampaikan bahwa telah terjadi perubahan yang sangat positif. Hal ini dapat diamati dari hasil analisis pada siklus I, yaitu hasil analisis observasi guru $58,3 \%$, hasil analisis observasi siswa sekitar 54\% dan hasil peningkatan keterampilan mendeskripsikan sebesar $41,17 \%$ dikarenakan banyak kekurangan di awal pembelajaran sehingga siswa belum menikmati. Sedangkan pada siklus II dapat diamati suatu peningkatan terjadi pada hasil analisis observasi guru sebesar $87,5 \%$ dan pada hasil analisis observasi siswa sebesar 83,3\% serta untuk hasil peningkatan kemampuan mendeskripsikan sebesar 82,35\%. Peningkatan yang cukup signifikan ini dikarenakan kekurangan pada siklus I diperbaharui dan guru menggunakan strategi baru yaitu bukan gambar dahulu namun huruf dahulu hingga siswa belajar kosakata lebih memahami dan menyenangkan. Dari paparan penjelasan di atas maka dapat disimpulkan bahwa buku cerita bergambar mampu meningkatkan keterampilan mendeskripsikan siswa kelas VI SD Negeri 015/VIII Sungai Bengkal Kabupaten Tebo Provinsi Jambi Tahun Pelajaran 2019/2020.

\section{KESIMPULAN}

Dari hasil penelitian yang telah diuraikan pada bab sebelumnya yang terkait dengan penelitian meningkatkan keterampilan mendeskripsikan siswa melalui media buku cerita bergambar di kelas VI SD Negeri 015/VIII Sungai Bengkal Kabupaten Tebo Provinsi Jambi Tahun Pelajaran 2019/2020, dapat disimpulkan bahwa penelitian yang telah dilakukan selama 2 bulan telah diperoleh hasil penelitian yang cukup memuaskan, yaitu bahwa media buku cerita bergambar dapat meningkatkan keterampilan mendeskripsikan siswa kelas VI SD Negeri 015/VIII Sungai Bengkal. Hal ini terbukti dari hasil penelitian yang telah dilakukan terjadi peningkatan secara signifikan dari sebelum tindakan sampai siklus II, yaitu: (1) pada observasi guru siklus I 58,3\% menjadi 87,5\% pada siklus II, (2) observasi siswa siklus I 54\% menjadi 83,3\% pada siklus II, dan (3) Pada hasil meningkatnya keterampilan mendeskripsikan siswa siklus I senilai $41,17 \%$ menjadi $82,35 \%$ pada siklus II.

\section{DAFTAR PUSTAKA}

Andriani, Septi dan Elhefni. 2015. "Pembelajara Mendeskripsikan Permulaan Melalui Metode Eja Bagi Siswa Berkesulitan Mendeskripsikan (Studi Kasus Mata Pelajaran Bahasa Indonesia Di Kelas III Madrasah Intidaiyah Quraniah VIII Palembang)”. (1): 153.

Chandra, C., Mayarnimar, M., \& Habibi, M. (2018). Keterampilan Mendeskripsikan dan Menulis Permulaan Menggunakan Model VARK untuk Siswa Sekolah Dasar. Jurnal Inovasi Pendidikan Dan Pembelajaran Sekolah Dasar, 2(1).

Farihatin, A. R. (2013). Kegiatan mendeskripsikan buku cerita dalam pengembangan kemampuan literasi dasar siswa usia dini (Doctoral dissertation, Universitas Muhammadiyah Surakarta).

Juwantara, R. A. (2019). Analisis Teori Perkembangan Kognitif Piaget Pada Tahap Siswa Usia Operasional Konkret 7-12 Tahun Dalam Pembelajaran Matematika. Jurnal Ilmiah Pendidikan Guru Madrasah Ibtidaiyah, 9(1), 27-34.

Mustadi, A. (2020). Landasan pendidikan sekolah dasar (Vol. 174). UNY Press.

Nurkhaula, S. (2018, March). Penggunaan Media Buku Cerita Bergambar untuk Meningkatkan Kemampuan Bahasa Siswa Kelompok B RA Riyadlul Jannah Wrati Kejayan Pasuruan. In PROCEEDING: The Annual International Conference on Islamic Education (Vol. 3, No. 2, pp. 338-346). 
Putri, D. P. (2018). Pendidikan karakter pada siswa sekolah dasar di era digital. AR-RIAYAH: Jurnal Pendidikan Dasar, 2(1), 37-50.

Rahayu, W., Winoto, Y., \& Rahman, A. S. (2016). Kebiasaan Mendeskripsikan Siswa Sekolah Dasar (Survei Aspek Kebiasan Mendeskripsikan Siswa SD Negeri 2 Pinggirsari di Desa Pinggirsari Kecamatan Arjasari Kabupaten Bandung). Khizanah al-Hikmah: Jurnal Ilmu Perpustakaan, Informasi, dan Kearsipan, 4(2), 152-162.

Smith, J. K., Smith, L. F., Gilmore, A., \& Jameson, M. (2012). Students' self-perception of reading ability, enjoyment of reading and reading achievement. Learning and individual differences, 22(2), 202-206.

Tanggulungan, Viktor Lambe, dkk. 2014. "Peningkatan Kemampuan Mendeskripsikan Permulaan Melalui Media Kartu Kata Siswa Kelas I SD Inpres Kamarora”. Jurnal Kreatif Tadulako. 5 (7): 227-228. 